\title{
Lenalidomide in Combination with Arsenic Trioxide: an Effective Therapy for Primary Effusion Lymphoma
}

\author{
Sara Moodad ${ }^{1,+}{ }^{-}$, Rana El Hajj ${ }^{2,+}$, Rita Hleihel ${ }^{1,3,+}$, Layal Hajjar $^{3}$, Nadim Tawil $^{4}$, \\ Martin Karam ${ }^{4}$, Maguy Hamie ${ }^{1,+}$, Raghida Abou Merhi ${ }^{5}$, Marwan El Sabban ${ }^{3}$ and \\ Hiba El Hajj ${ }^{4, *}$ \\ 1 Department of Internal Medicine, Faculty of Medicine, American University of Beirut, \\ Beirut 202627, Lebanon; shm24@mail.aub.edu (S.M.); rh150@aub.edu.lb (R.H.); mh242@aub.edu.lb (M.H.) \\ 2 Department of Pathology and Laboratory Medicine, Faculty of Medicine, American University of Beirut, \\ Beirut 202627, Lebanon; rh164@aub.edu.lb \\ 3 Department of Anatomy, Cell Biology, and Physiology, Faculty of Medicine, American University of Beirut, \\ Beirut 202627, Lebanon; lh85@aub.edu.lb (L.H.); me00@aub.edu.lb (M.E.S.) \\ 4 Department of Experimental Pathology, Immunology, and Microbiology, Faculty of Medicine, \\ American University of Beirut, Beirut 202627, Lebanon; nadim.tawil@mail.mcgill.ca (N.T.); \\ martin.karam@mail.mcgill.ca (M.K.) \\ 5 Department of Biology, Faculty of Sciences, GSBT laboratory, Lebanese University, Hadath 31143, Lebanon; \\ raboumerhi@ul.edu.lb \\ * Correspondence: he21@aub.edu.lb; Tel.: +961-1350000 (ext. 4897) \\ + The authors contributed equally to this work.
}

Received: 2 July 2020; Accepted: 23 July 2020; Published: 1 September 2020

check for updates

\begin{abstract}
Primary effusion lymphoma (PEL) is a rare aggressive subset of non-Hodgkin B cell lymphoma. PEL is secondary to Kaposi sarcoma herpes virus (KSHV) and predominantly develops in serous cavities. Conventional chemotherapy remains the treatment of choice for PEL and yields high response rates with no significant comorbidities. Yet, chemotherapy often fails in achieving or maintaining long-term remission. Lenalidomide (Lena), an immunomodulatory drug, displayed some efficacy in the treatment of PEL. On the other hand, arsenic trioxide (ATO) in combination with other agents effectively treated a number of blood malignancies, including PEL. In this study, we present evidence that the combination of ATO/Lena significantly enhanced survival of PEL mice, decreased the volume of exacerbated ascites in the peritoneum, and reduced tumor infiltration in organs of treated animals. In ex vivo treated PEL cells, ATO/Lena decreased the proliferation and downregulated the expression of KSHV latent viral proteins. This was associated with decreased NF- $\mathrm{KB}$ activation, resulting in reactivation of viral replication, downregulation of interleukin-6 (IL-6) and IL-10, inhibition of vascular endothelial growth factor, and apoptosis. Our results elucidate the mechanism of action of ATO/Lena and present it as a promising targeted therapeutic modality in PEL management, which warrants further clinical investigation.
\end{abstract}

Keywords: HHV-8; immunomodulatory drugs; LANA; latent cycle; lytic cycle; lymphoma

\section{Introduction}

Primary effusion lymphoma (PEL) is an aggressive non-Hodgkin B-Cell lymphoma (NHL) secondary to Kaposi sarcoma herpes virus (KSHV) [1,2]. This virus originally described as acquired immunodeficiency syndrome (AIDS)-associated Kaposi sarcoma [3], was later referred to as human herpesvirus type 8 (HHV-8) [1,2,4]. PEL accounts for around $4 \%$ of human immunodeficiency virus (HIV)-associated NHL and less than $1 \%$ of non-HIV-related lymphomas [5]. It typically occurs in middle-aged immunocompromised patients, infected either with HIV or recipients of solid-organ 
transplants, and in elderly patients in HHV-8 endemic areas [6-10]. Clinically, PEL typically presents as body cavity lymphoma with malignant lymphomatous effusions invading peritoneal, pleural, and/or pericardial cavities [2,11]. Extra-cavitary PEL with solid tumor masses is less frequent, and when present, it involves organs adjacent to the cavitary space, regional lymph nodes, and gastrointestinal tract among others [12,13].

KSHV transforms B lymphocytes [5,14] and associates with several malignancies [14-16]. In PEL, the KSHV genome is present in all neoplastic cells, and its detection is crucial for definitive diagnosis [15-17]. KSHV oncogenesis involves latent and lytic phases [1,17], but the virus mostly resides in B cells in its latent phase, where PEL malignant cells express KSHV-encoded latent proteins including latency-associated nuclear antigen-1 (LANA-1/ORF73), LANA-2/vIRF-3, viral cyclin (v-Cyclin), and viral FLICE inhibitory protein (v-FLIP) [2,17-21]. LANA-1 is crucial for maintaining viral latency and viral episomes [18-21], and its presence is a standard method for diagnosis of PEL [22,23]. LANA-1 also impairs apoptosis by inhibiting p53 and retinoblastoma $(\mathrm{Rb})$ tumor suppressor proteins, yielding tumor growth and survival $[19,24]$. It also contributes to the dysregulation of the NOTCH pathway and the inhibition of lytic gene expression [25]. LANA-2, another viral latent protein, impairs p53-mediated apoptosis and prevents p53 SUMOylation leading to cell senescence [26]. It also plays a substantial role in the development of drug resistance to anti-mitotic drugs by reducing polymerized microtubules stability [27]. v-Cyclin, the viral homologue of cellular cyclin D, drives cell cycle progression through binding and constitutively activating cyclin-dependent kinases 4 and 6 (CDK6) resulting in $\mathrm{Rb}$ phosphorylation and inactivation [28]. v-FLIP, the viral homologue of FLICE inhibitor protein (c-FLIP) promotes tumor proliferation, cell survival [29], and inhibits apoptosis by blocking death receptor Fas-and TNF mediated caspase activation [30,31]. v-Cyclin and v-FLIP constitutively activate the NF- $\mathrm{kB}$ pathway, which plays a key role in PEL tumorigenesis, while maintaining viral latency [32-35]. In addition to the aforementioned latent viral proteins, PEL cell survival depends on the production of cytokines that serve as autocrine growth factors [36,37]. These include cellular IL-10 and IL-6, which are secreted by PEL cells and promote cellular proliferation and tumor progression [36-38].

Given the rarity of PEL, treatment and management of the disease are limited to very few randomized or retrospective studies. An optimal curative regimen for PEL is lacking [11]. Chemotherapy remains the current treatment of PEL patients and leads to good response rates with no significant comorbidities. The chemotherapy regimen includes cyclophosphamide/doxorubicin/ vincristine/prednisone (CHOP) or dose adjusted etoposide/prednisolone/vincristine/cyclophosphamide/ doxorubicin (DA-EPOCH) [11,39]. In HIV positive PEL patients, highly active antiretroviral therapy (HAART) is often preferred. However, remission is not sustainable due to high relapse rates and resistance of PEL patients to chemotherapy $[2,40,41]$, and the median survival does not exceed six months $[11,41]$.

Lenalidomide (Lena) is an immunomodulatory agent and a thalidomide analogue approved for the treatment of multiple myeloma patients [42,43]. Lena, via its anti-angiogenic, anti-neoplastic, and immune activating properties showed promising efficacy in numerous hematological malignancies [43-45]. PEL cells treated in vitro with Lena were cell cycle arrested [46], and immune surface markers downregulated by KSHV were restored as an immune-modulatory mechanism [47]. Among its known mechanisms of action, Lena targeted the IKZF1-IRF4-MYC axis in a cereblon-dependent manner [46]. Lena also degraded IKZF1, a specific B-cell transcription factor, leading to the down-regulation of IRF4 transcript levels and MYC expression, known to be essential for PEL survival and proliferation [46]. A phase I/II clinical study investigating Lena with DA-EPOCH and rituximab is ongoing (NCT02911142). Furthermore, a 77-year-old HIV-negative patient achieved complete remission after receiving Lena. Remission was sustained after 18 months of therapy [48].

Arsenic trioxide (ATO), in combination with various drugs, is a highly effective compound against several hematological malignancies [49-51]. Mechanisms of action of ATO are versatile and include induction of apoptosis, inhibition of proliferation and angiogenesis, stimulation of differentiation, and deregulation of cellular redox states [52]. In PEL, ATO combined with interferon- $\alpha$ (IFN $\alpha$ ) inhibited 
cell proliferation and induced apoptosis in vitro [53]. In a PEL murine model, ATO/IFN $\alpha$ prolonged survival, induced apoptosis, and decreased viral latent gene transcripts [54]. Even though results were promising, a cure was not achieved. In this study, we demonstrate that ATO/Lena not only significantly enhanced the survival of PEL mice but also achieved a cure in some mice. In addition, ATO/Lena decreased the volume of effusion in the peritoneum and reduced tumor infiltration in organs of treated animals. In ex vivo treated cells, ATO/Lena decreased proliferation and downregulated the expression of latent viral proteins. This downregulation resulted in decreased NF- $\kappa$ B activation, downregulation of cellular IL-6 and IL-10, reactivation of viral replication, and apoptosis. These results present this combination as an encouraging therapeutic option for PEL patients.

\section{Results}

\subsection{ATO/Lena Enhances Survival and Reduces Lymphomatous Effusions in PEL Mice}

NOD/SCID mice were intraperitoneally injected with the PEL cells (BC-3 or BCBL-1) (Ethical permit number \#15-07-P575). On day 4 post-inoculation of PEL cells, mice were treated with ATO, Lena, or their combination for one month and assessed for survival (timeline described in Figure 1a). In mice injected with BC-3 cells, the median survival significantly increased from 63 days in untreated mice to $163(p=0.012)$ in mice treated with ATO or 85 days $(p<0.005)$ in mice treated with Lena alone. The median survival was strikingly increased to 272 days $(p=0.018)$ upon treatment with the ATO/Lena combination, and $25 \%$ of treated mice were completely cured, with no effusion formation, after more than one year post-injection of lymphomatous cells. Similarly, in mice injected with BCBL-1 cells, the median survival significantly increased from 78 days in untreated mice to $163(p=0.014)$ and 263 days $(p=0.016)$ in mice treated with ATO or Lena single agents, respectively. In Lena treated mice, $25 \%$ of mice were cured. Importantly, this median survival reached 360 days in ATO/Lena-treated mice $(p=0.016)$, and $75 \%$ of the mice were totally cured after over a year post-injection of malignant BCBL-1 cells. These results demonstrate not only enhanced survival but also a strong curative effect of the ATO/Lena combination.

We then assessed the effect of therapeutic efficacy of ATO/Lena on PEL progression after development of lymphomatous effusion. NOD/SCID mice were thus inoculated with BC-3 or BCBL-1 cells and allowed to develop tumors for six weeks. Mice were then treated with ATO, Lena, or their combination, and the ascites and peritoneal volume were monitored on a daily basis. A moderate and none significant effect on ascites and peritoneal volume was seen in PEL mice injected with BC-3 or BCBL-1 cells upon treatment with single therapy. Within two days, a remarkable difference in the peritoneal effusion was noticed upon treatment with the combination. This prompted us to sacrifice the animals after a week of treatment to study the mechanism in detail. ATO/Lena significantly decreased ascites and peritoneal volumes (Figure $1 \mathrm{~b}$ and Figure S1). Indeed, in mice injected with BC-3 cells, the mean volume of peritoneal ascites decreased from $4 \mathrm{~mL}$ in untreated controls, to $2 \mathrm{~mL}$ in mice treated with the combination $(p<0.01)$ (Figure $1 \mathrm{~b})$. The mean peritoneal volume was also decreased to $40 \%$ in ATO/Lena treated mice (Figure S1) $(p<0.001)$. Similarly, in mice injected with BCBL-1 cells, the mean volume of peritoneal ascites decreased from $7 \mathrm{~mL}$ in untreated control to $1.4 \mathrm{~mL}$ in ATO/Lena-treated mice ( $p<0.001)$, and the mean peritoneal volume decreased to $28 \%$ in mice treated with the combination $(p<0.001)$ (Figure $1 \mathrm{~b}$ and Figure S1). Collectively, these results demonstrate that the ATO/Lena combination reduces effusion and enhances survival in PEL mice.

\subsection{ATO/Lena Inhibits Proliferation and Downregulates KSHV Latent Proteins in Ex Vivo Ascites-Derived PEL Cells}

BC-3 and BCBL-1 cells derived from malignant peritoneal ascites in PEL mice were treated ex vivo with ATO and/or Lena. A moderate but significant effect on cell proliferation was obtained upon treatment with ATO or Lena single agents, starting $48 \mathrm{~h}$ post treatment of both ascites-derived PEL cells $(p<0.05)$. Interestingly, treatment with ATO/Lena resulted in a more pronounced anti-proliferative 
effect in both BC-3 $(p<0.01)$ and BCBL-1 $(p<0.001)$ at 48 and $72 \mathrm{~h}$ post treatment (Figure 2a). Moreover, BCBL-1 ascites-derived cells were more sensitive to the ATO/Lena combination than BC-3 cells (Figure 2a).

a
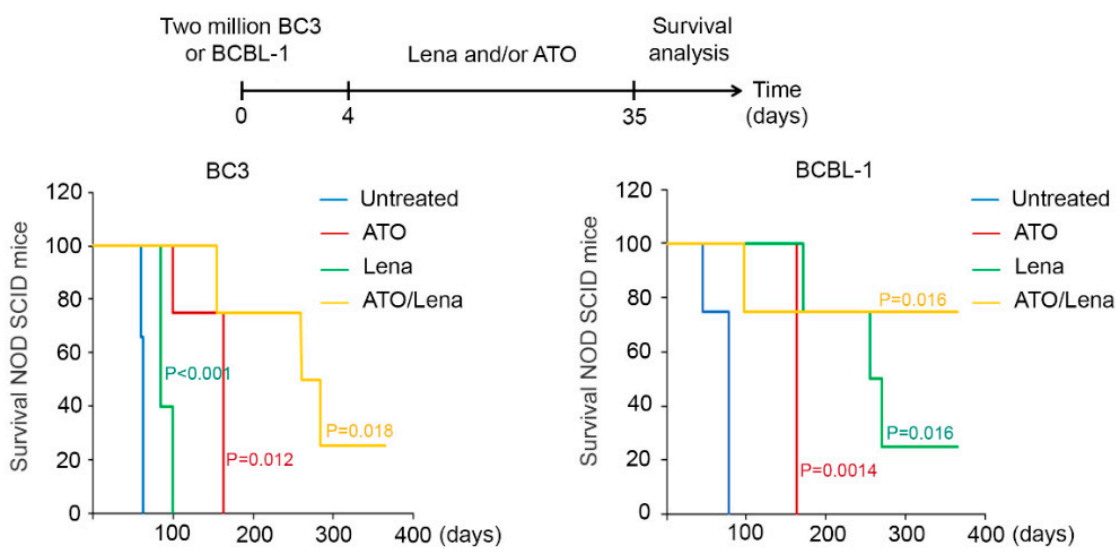

b
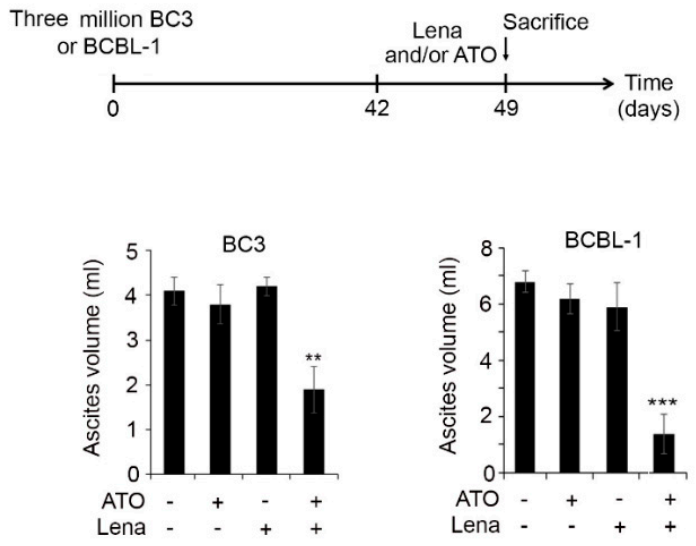

Figure 1. Arsenic trioxide/Lenalidomide (ATO/Lena) enhanced survival and decreased ascites volume in NOD/SCID primary effusion lymphoma (PEL) mice. (a) Kaplan-Meier graphs of overall survival curves of BC-3 (left) and BCBL-1 (right) NOD/SCID mice. Mice ( $n=4$ per condition) were injected with 2 million BC-3 or BCBL-1 cells. ATO, Lena, or their combination were administered from day 4 until day 35 post-injection of PEL cells. (b) Ascites volume from BC-3 (left) or BCBL-1 (right). PEL mice were allowed to develop ascites for 6 weeks then were treated daily with ATO, Lena, or their combination for one week before sacrifice. $\left(^{* *}\right)$ indicates $p<0.01$; and $\left(^{* * *}\right)$ indicates $p<0.001$.

To dissect the anti-proliferative effect of ATO/Lena on PEL cells, we first tested the expression of KSHV latent proteins, known to play a key role in PEL oncogenesis [2,17-21]. Interestingly, the ATO/Lena combination resulted in the decreased protein expression of both LANA-1 and LANA-2 proteins, at $48 \mathrm{~h}$ post treatment, in both BC-3 and BCBL-1 ascites-derived cells (Figure $2 \mathrm{~b}$ and Figure S2). Similarly, while no significant effect of a single agent was observed, ATO/Lena significantly decreased KSHV latent v-FLIP and v-Cyclin transcript levels in BC-3 ascites-derived cells $(p<0.01)$ (Figure 2c). In BCBL-1 ascites-derived cells, ATO or Lena single agent treatment yielded a significant, albeit moderate, decrease in v-FLIP and v-Cyclin transcript levels $((p<0.05$ and 0.01 , respectively). Yet, this decrease was more pronounced upon treatment with the ATO/Lena combination $(p<0.01)$ (Figure 2c). The decrease in cellular proliferation and the reduction of expression of viral latent proteins may explain the enhanced survival and the decrease in peritoneal effusion. 

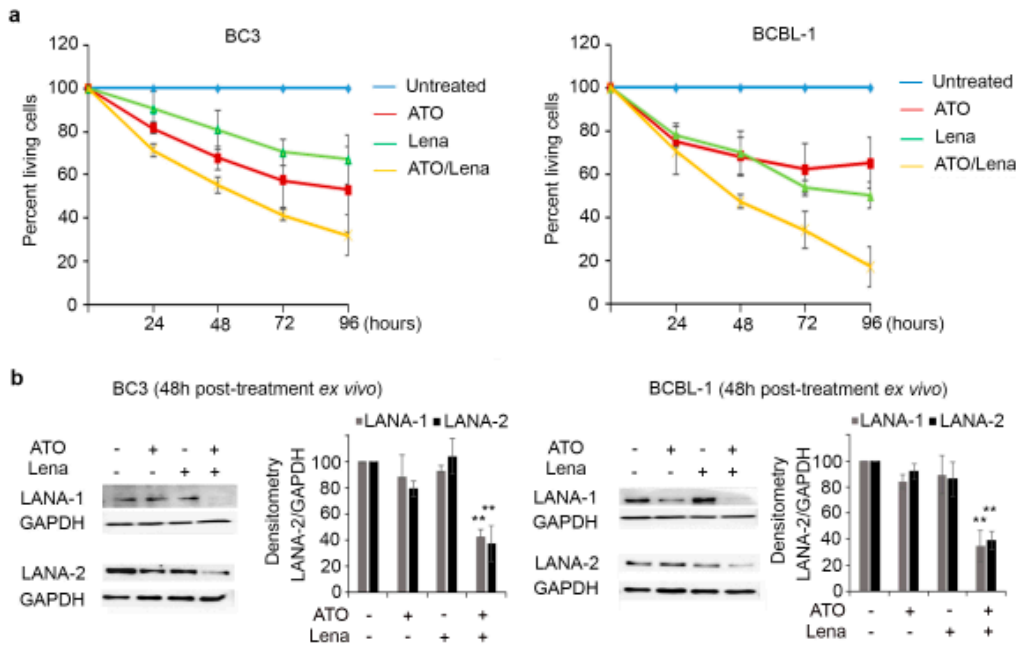
BC3 (48h post-treatment ex vivo)
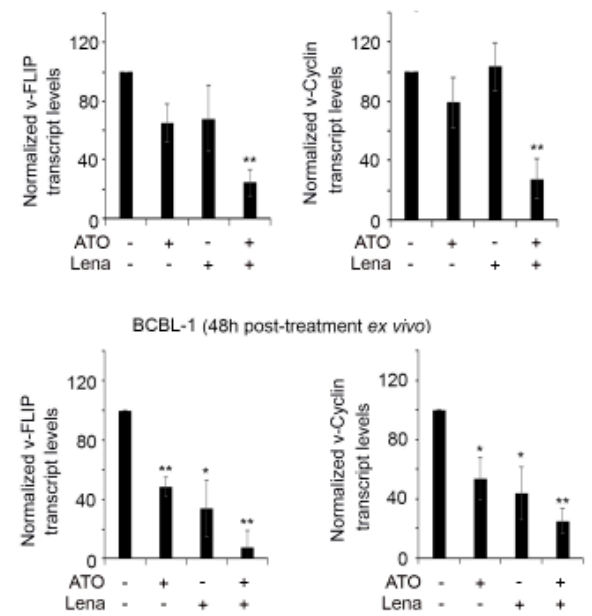

Figure 2. ATO/Lena inhibited proliferation and downregulated Kaposi sarcoma herpes virus (KSHV) latent transcripts and proteins in ex vivo treated ascites-derived BC-3 and BCBL- 1 cells. (a) Cell proliferation of ascites-derived BC-3 (left) or BCBL-1 cells (right) following ex vivo treatment with ATO and/or Lena for 24, 48, 72, and $96 \mathrm{~h}$. Results are presented as percent of control, plotted as mean $\pm \mathrm{SD}$, and represent an average of three independent experiments. (b) Immunoblot analysis of KSHV latent proteins LANA-1 and LANA-2 in ascites-derived BC-3 (left) or BCBL-1(right) cells treated ex vivo for $48 \mathrm{~h}$ with ATO, Lena, or their combination. Densitometry histograms represent an average of 3 independent experiments. Uncropped blots of Figure 2b are shown in Figure S5 (c) Real-time quantitative PCR analysis of transcript levels of KSHV latent genes v-FLIP and v-Cyclin in ascites-derived BC-3 (left) or BCBL-1(right), $48 \mathrm{~h}$ post treatment with ATO, Lena, or the ATO/Lena combination. Results represent the average of 3 independent experiments. $\left.{ }^{*}\right)$ indicates $p<0.05$; $(* *)$ indicates $p<0.01$.

\subsection{ATO/Lena Decreases Tumor Burden through Inhibiting Autocrine Cytokines in Ex Vivo Ascites-Derived PEL Cells}

Prior studies demonstrated an important role of v-FLIP in the activation of NF- $\mathrm{kB}$, a constitutively activated pathway with pivotal roles in PEL progression and survival [29,32,35]. In accordance with the decreased v-FLIP expression, we demonstrated that ATO/Lena decreased phosphorylation of $\mathrm{I} \kappa \mathrm{B} \alpha$ protein in both BC-3 and BCBL-1 ascites-derived cells at $48 \mathrm{~h}$ post treatment (Figure 3a). This was consistent with the decreased nuclear translocation of $\mathrm{p} 65$, a mandatory subunit for the activation of 
NF- $\mathrm{kB}$ pathway, in both BC-3 and BCBL-1 cells, while ATO or Lena alone did not display any effect on p65 translocation (Figure 3a).
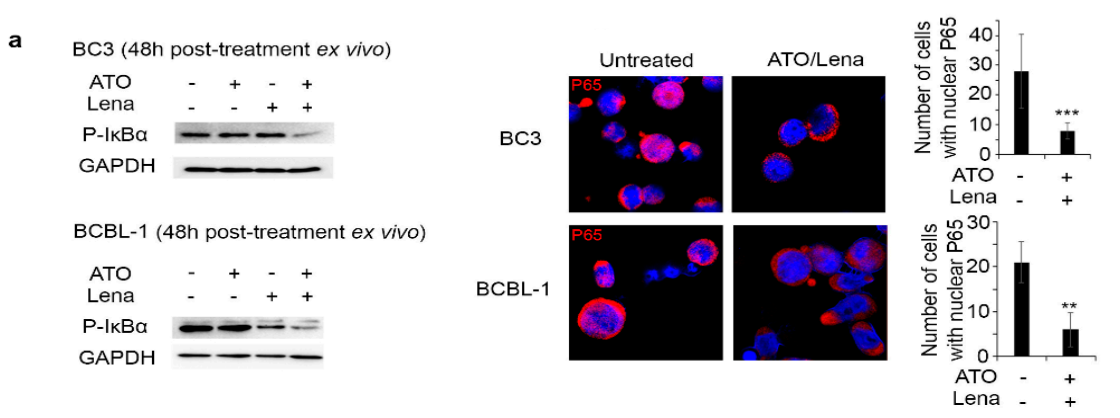

b
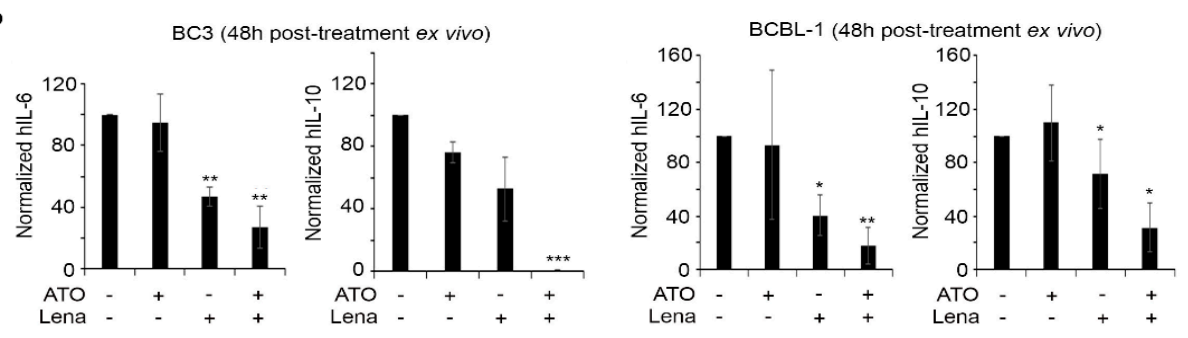

c
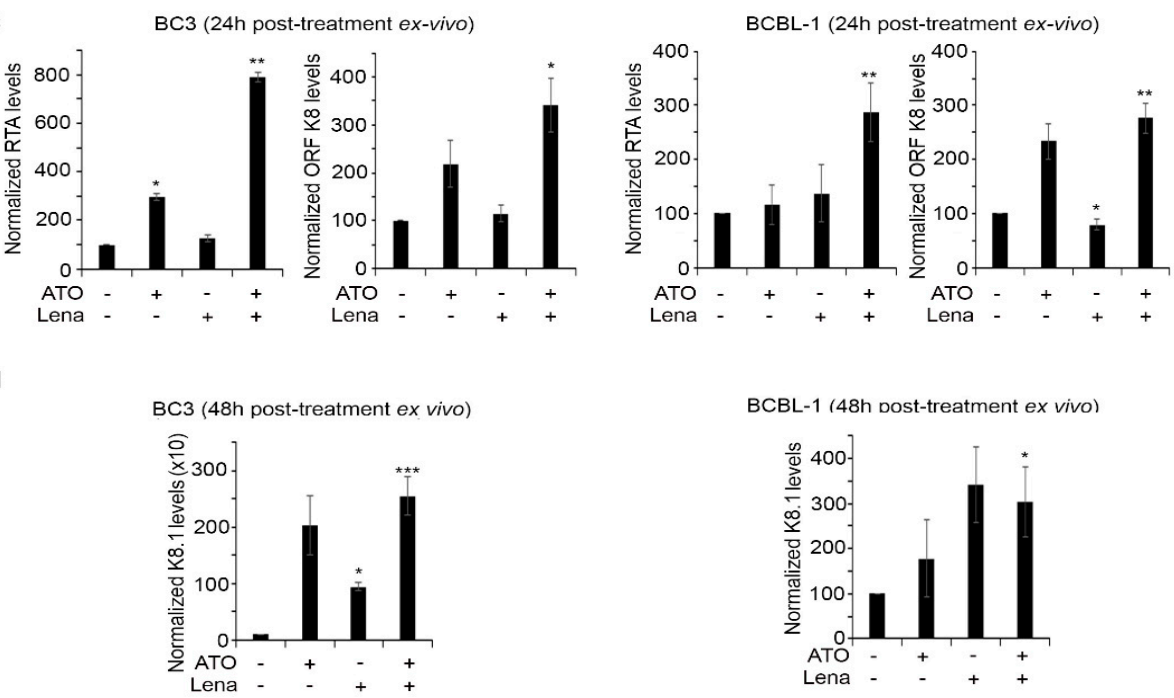

Figure 3. ATO/Lena inhibited NF- $\mathrm{BB}$ activation and increased KSHV reactivation in ex vivo treated ascites-derived BC-3 and BCBL-1 cells. (a) Western blot analysis of $\mathrm{p}-\mathrm{I} \mathrm{KB} \alpha$ in ATO/Lena ex vivo treated ascites-derived BC-3 and BCBL-1 cells $48 \mathrm{~h}$ post treatment. Confocal microscopy analysis of p65 nuclear translocation in ascites-derived BC-3 and BCBL-1 after ex vivo treatment with ATO/Lena for $48 \mathrm{~h}$. p65 was stained with anti-p65 antibody (red) and nuclei were stained by Hoechst stain (blue). Images represent z-sections. Histograms represented number of cells with nuclear p65 translocation. Uncropped blots of Figure 3a are shown in Figure S5. (b) Real-time quantitative PCR showing transcript levels of human IL-6 and IL-10 cytokines in ascites-derived BC-3 (left) and BCBL-1 (right) cells $48 \mathrm{~h}$ following ex vivo treatment with ATO and/or Lena. (c,d) Real-time quantitative PCR analysis of transcript levels of KSHV early-lytic genes (RTA, ORFK8) (c) or late lytic gene (K8.1) (d) in ascites-derived BC-3 (left) and BCBL-1 (right) cells after ex vivo treatment with ATO and/or Lena for 24 (c) or $48 \mathrm{~h}(\mathbf{d})$ as indicated. Results represent the average of 3 independent experiments. $\left(^{*}\right)$ indicates $p<0.05 ;(* *)$ indicates $p<0.01$; and $\left({ }^{* * *}\right)$ indicates $p<0.001$. 
NF- $\kappa B$ transactivates the expression of several cytokines, including cellular IL-6 and IL-10. In both BC-3 and BCBL-1 ascites-derived cells, ATO as a single agent had no significant effect on cellular IL-6, while Lena alone significantly decreased cellular IL-6 transcripts in both BC-3 $(p<0.01)$ and BCBL-1 cells $(p<0.05)$ to more than $50 \%$ as compared to untreated controls (Figure $3 \mathrm{~b}$ ). Single agent treatment with ATO or Lena had no effect on cellular IL-10 transcript levels. Importantly, the ATO/Lena combination significantly decreased IL- 6 transcripts to $27 \%(p<0.01)$ and totally abrogated IL-10 expression $(p<0.001)$ in BC-3-ascites-derived cells. In BCBL-1 ascites-derived cells, a similar decrease to $18 \%$ in cellular IL-6 $(p<0.01)$ and to $31 \%$ in cellular IL-10 $(p<0.05)$ was obtained (Figure $3 b)$. Hence, it is conceivable to explain the reduction in cellular proliferation due to the treatment as converging pathways through decreasing NF- $\mathrm{kB}$, leading to the subsequent decrease in the transcription of autocrine cytokines necessary for PEL cell survival.

\subsection{ATO/Lena Induces KSHV Lytic Gene Expression in Ex Vivo Ascites-Derived PEL Cells}

In PEL, NF- $\mathrm{KB}$ constitutive activation inhibits KSHV reactivation and lytic gene expression $[55,56]$. In contrast, KSHV reactivation and increased lytic gene expression is often paralleled with decreased latent transcription and apoptosis [21]. Interestingly, the ATO/Lena combination resulted in significant induction of early RTA and ORFK8 lytic transcript levels at $24 \mathrm{~h}$ and late lytic gene transcripts (ORFK8.1) at $48 \mathrm{~h}$ post treatment of ex vivo ascites-derived PEL cells (Figure 3c,d). Indeed, in BC-3 ascites-derived cells, ATO alone resulted in a moderate significant increase of RTA transcripts $24 \mathrm{~h}$ post treatment $(p<0.05)$, while the Lena single agent had no effect (Figure 3c). The combination of ATO/Lena resulted in a sharp and significant increase in RTA expression $24 \mathrm{~h}$ post treatment $(p=0.01263)$. Similar results were observed in ORF K8 transcripts $(p=0.0177)$ upon treatment with the combination for $24 \mathrm{~h}$, while no significant effects of single agents were observed (Figure 3c). The effect of the ATO/Lena combination was similar in BCBL-1 derived ascites, whereby $24 \mathrm{~h}$ of treatment resulted in a significant and sharp increase of both early lytic gene transcripts RTA $(p<0.05)$ and ORF K8 $(p<0.01)$ (Figure 3c). We then interrogated the late lytic gene K8.1 expression at $48 \mathrm{~h}$ post treatment of ascites-derived PEL cells and demonstrated a significant increase of transcript levels upon treatment with the ATO/Lena combination, in both ascites-derived BC-3 $(p<0.01)$, and BCBL-1 cells $(p<0.05)$ (Figure 3d).

\subsection{ATO/Lena Induces Apoptosis in Ex Vivo Ascites-Derived PEL Cells}

Inhibition of NF-KB induces apoptosis in PEL cells in vitro [57]. In both ascites-derived BC-3 and BCBL-1 cells, the combination of ATO/Lena induced a prominent cleavage of procaspase-3, a crucial mediator of apoptosis, and an increased expression of cleaved caspase-3 protein (Figure 4). Consistent with these results, PARP-1, a downstream target of caspase-3, was also cleaved in both ascites-derived BC-3 and BCBL-1 cells $48 \mathrm{~h}$ post treatment with the combination of ATO/Lena (Figure 4), indicating the induction of apoptosis. A similar experiment was also performed with DAPI staining (Figure S3). This allows the evaluation of the percentage of chromatin condensation, which is a hallmark of apoptosis.

\subsection{ATO/Lena Inhibits VEGF-Dependent Endothelial Cells Tube Formation}

In BC-3 injected mice, we noticed a decreased peritoneal vascularization upon treatment with the combination of ATO/Lena (Figure 5A). The anti-angiogenic effect of Lena was previously documented in numerous blood malignancies [58,59]. PEL cells are also known to secrete VEGF into ascitic fluids in vivo, promoting VEGF-dependent angiogenesis and PEL progression $[60,61]$. We investigated the effect of ATO/Lena on VEGF-dependent angiogenesis. HAECs were seeded onto growth factor-reduced Matrigel and incubated with treated or untreated ascites-derived PEL (BC-3 or BCBL-1) cell-free supernatant for $48 \mathrm{~h}$. When cultured alone, HAEC cells failed to form structured tubes. In contrast, the addition of supernatants from untreated ascites-derived BC-3 and BCBL-1 cells resulted in capillary-like tubes with multi-centric junctions (Figure 5B). Supernatant from ATO or Lena treated BC-3 or BCBL-1 cells had no or minimal effects on tubal formation capacity. In contrast, supernatant 
from ascites of ATO/Lena treated BC-3 PEL mice resulted in a significant reduction in the capillary-like tube formation capacity compared to untreated cells, while no effect of this combination was observed in BCBL-1 PEL mice, presumably due to either the relatively low amount of Bevacizumab or the overwhelming amount of VEGF secreted by BCBL-1 [61]. This suggests that reduction in VEGF-induced angiogenesis may be one of the mechanisms contributing to ATO/Lena eradication of ascites-derived BC-3 but not BCBL-1 cells.
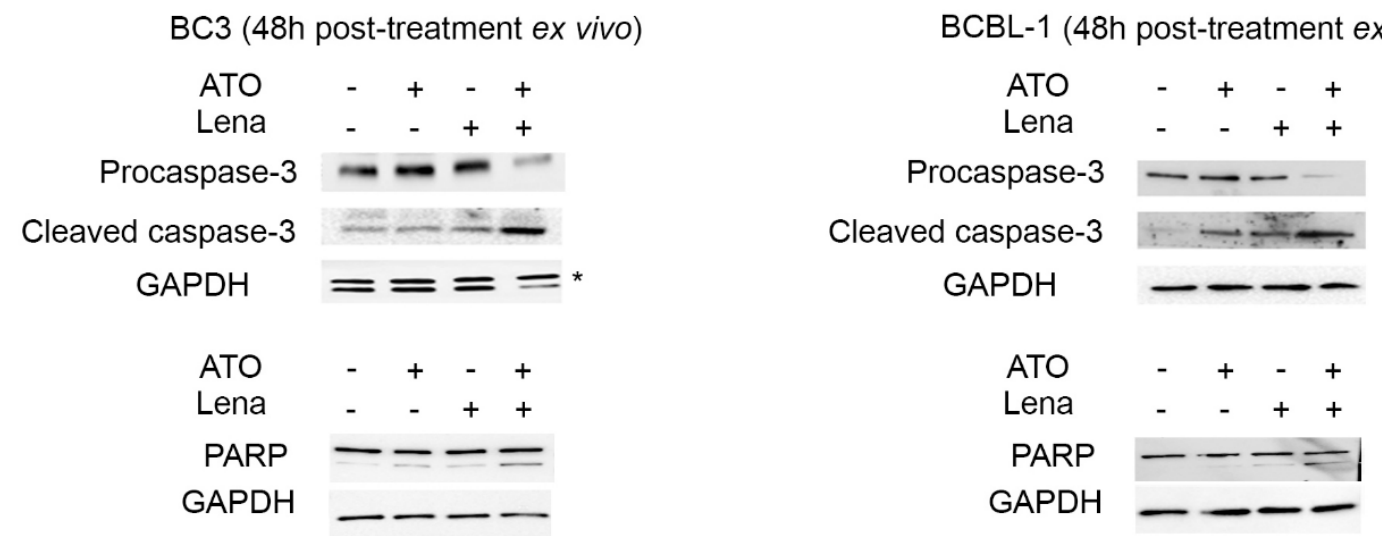

Figure 4. The ATO/Lena combination induced apoptosis in ex vivo treated ascites-derived BC-3 and BCBL-1 cells. Western blot analysis of PARP, procaspase-3, and cleaved caspase-3 levels in ascites-derived BC-3 (left) and BCBL-1 (right) cells $48 \mathrm{~h}$ post treatment as indicated. Uncropped blots are shown in Figure S5.

\subsection{ATO/Lena Decreases Organ Infiltration and Downregulates Latent KSHV Proteins and Cytokine Expression In Vivo}

To investigate the in vivo effect and mechanism of action of the ATO/Lena combination, PEL mice were left to form lymphomatous effusion for 6 weeks before treatment for one week with the ATO/Lena combination. We first examined the effect of this therapeutic regimen on organ infiltration. Compared to control mice, ATO/Lena treated mice exhibited decreased infiltration of PEL cells in lungs and livers of both BC-3 and BCBL-1 models (Figure 6a). Consistent with ex vivo data, ATO/Lena treatment decreased LANA-1 and LANA-2 protein expression in effusions of treated BC-3 and BCBL-1 mice. We then questioned whether this decrease was merely a result of decreased percentage of PEL cells in collected ascites. CD45 staining of ascites from ATO/Lena BC-3 treated mice showed no significant variation in the number of PEL cells as compared to untreated mice (Figure S4). Thus, the obtained decrease in LANA-1 and LANA-2 proteins upon treatment with ATO/Lena is not due to less PEL cells, but rather an effect of this combination on viral protein expression (Figure $6 \mathrm{~b}$, left panel). In BCBL-1 mice, treatment with ATO, Lena, or their combination affected the number of peritoneal PEL cells, with a significant reduction by $50 \%$ in the percentage of CD45 positive cells in ATO/Lena treated mice (Figure S4). We thus sorted CD45 positive BCBL-1 cells before assessing the effect of the combination on viral protein expression in BCBL-1 ascites-derived cells, and we demonstrated that the ATO/Lena combination also decreased LANA-1 and LANA-2 protein expression in these cells (Figure $6 \mathrm{~b}$, right panel). We also observed a decreased transcript expression of both cellular IL-6 and IL-10 in the lungs of ATO/Lena treated PEL mice. The decrease of IL- 6 was significant in the BC-3 model and reached $25 \%(p<0.05)$, while the decrease of both IL- 6 and IL-10 was significant in the BCBL-1 model and reached 25\% $(p<0.05)$ and $45 \%(p<0.05)$, respectively. Overall, these data validate the above ex vivo dissected mechanism of action of the ATO/Lena combination in vivo. 
A

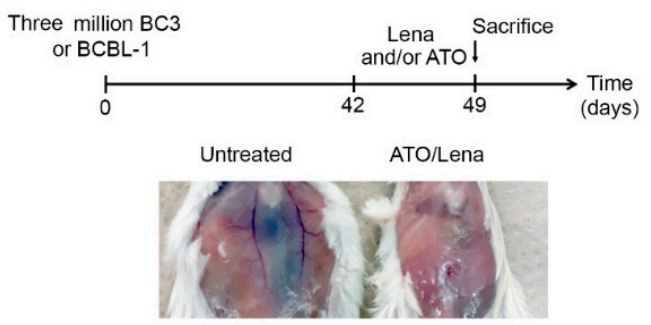

B
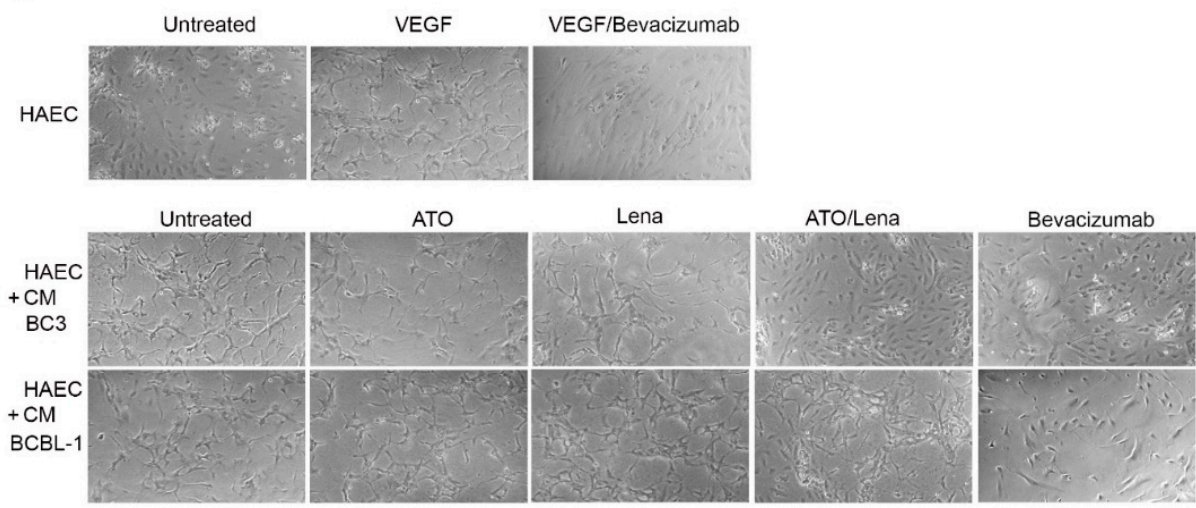

C
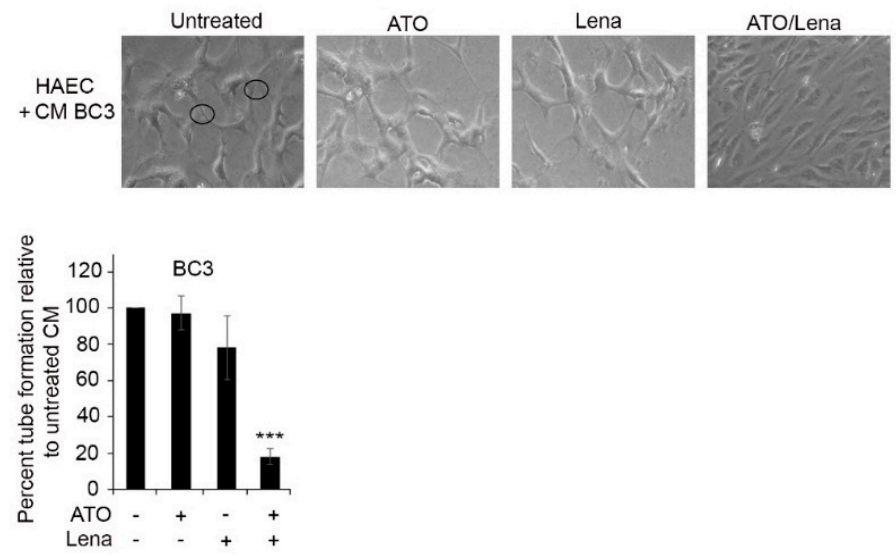

Figure 5. ATO/Lena decreased VEGF-induced tubal formation potential of ascites-derived BC-3 but not BCBL-1 cells. (A) Mice peritoneum vascularization before and after one-week treatment with ATO/Lena in BC-3 PEL mice. (B) Light microscopy images of capillary-like tube formations in HAEC cells following incubation with supernatants from ex vivo treated ascites-derived BC-3 or BCBL-1 cells. (C) Tubal formation analysis method where nodes with 3 or more branches were counted and compared. At least 5 images from each condition were counted. Data was reported as a histogram of the percentage of tube formation relative to untreated ascites-derived BC-3 cells. Data represent an average of 3 independent experiments. $\left.{ }^{* * *}\right)$ indicates $p<0.001$. 
a

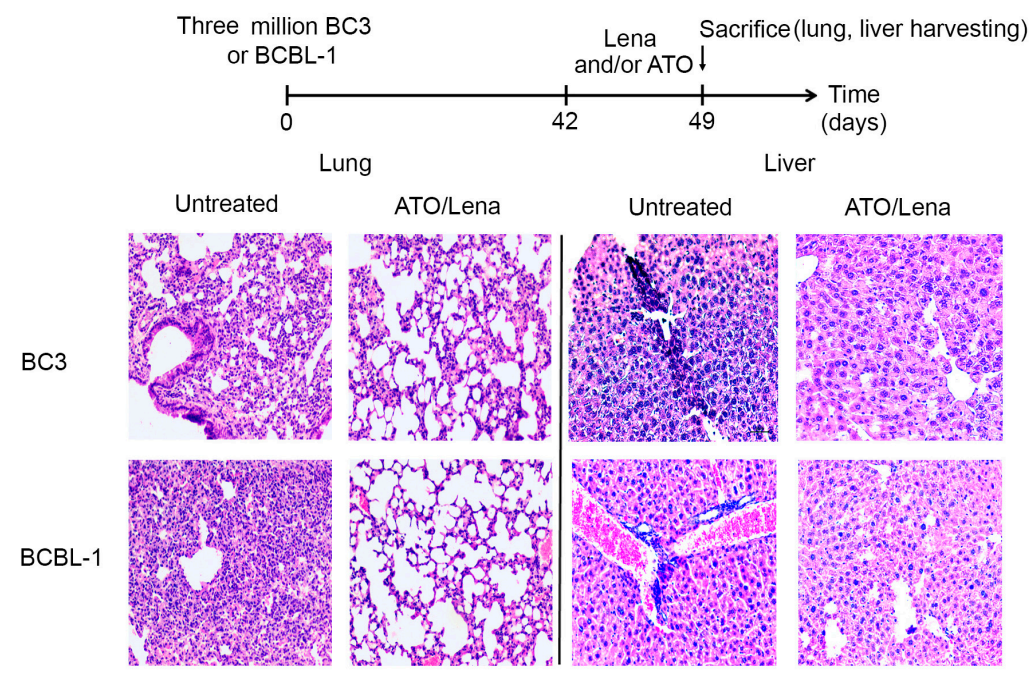

b
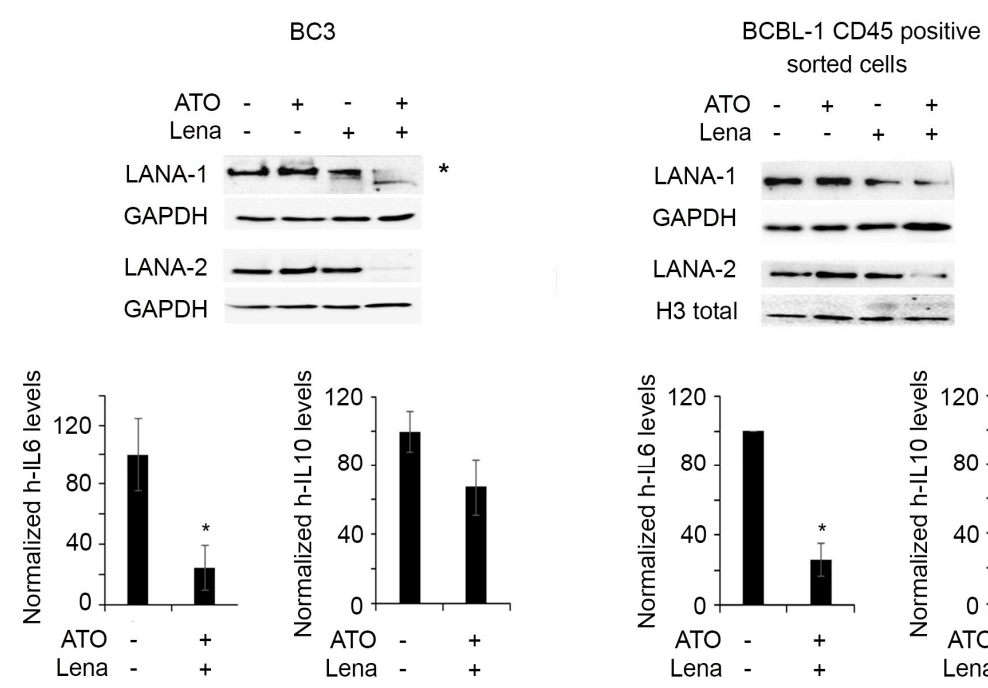

Figure 6. ATO/Lena decreased organ infiltration and downregulated latent KSHV proteins in vivo. (a) Experimental design: mice injected with BC-3 or BCBL-1 were allowed to develop ascites for 6 weeks, were treated with ATO and/or Lena for one week, then were sacrificed. Histopathology sections of lung and spleens from ATO/Lena treated or untreated BC-3 and BCBL-1 PEL mice. (b). Immunoblot analysis of LANA-1 and LANA-2 proteins in whole ascites (left) or CD45+ sorted ascites (right) derived from treated or untreated BC-3 and BCBL-1 mice respectively. Uncropped blots of Figure $6 \mathrm{~b}$ are shown in Figure S5. (c) Real-time quantitative PCR analysis of cellular IL-6 and IL-10 transcript levels in lungs of ATO/Lena treated or untreated BC-3 and BCBL-1 mice as indicated. Transcript levels were normalized to GAPDH internal levels. $\left({ }^{*}\right)$ indicates $p<0.05$

\section{Discussion}

PEL has a dismal prognosis due to significant challenges that include chemo-resistance, lack of large-scale randomized clinical trials, and high relapse rates. Currently, chemotherapy remains the cornerstone treatment for managing PEL, yet, the overall survival rate is limited to a year in only $40 \%$ of CHOP-treated patients [11,40]. The combination of ATO and IFN induced cell death and enhanced survival in PEL mice [53]. Despite its significant effect, this combination did not result in a cure. Administration of Lena alone to a PEL patient led to complete and long lasting remission [48]. In addition, a phase I/II clinical study is being performed investigating Lena with chemotherapy and rituximab (NCT02911142). Collectively, this guided our current investigation. The combination of ATO with different agents proved efficient in several blood malignancies. The combination of ATO with retinoic acid became the standard clinical regimen to cure acute promyelocytic leukemia [49]. Similarly, 
this combination resulted in selective cell death of acute myeloid leukemia with nucleophomin-1 mutation [62,63] and significantly reduced leukemic blasts in patients [62]. In adult $\mathrm{T}$ cell leukemia (ATL), ATO synergized with IFN $\alpha$ to selectively induce apoptosis of ATL cells [64], cured the disease in a murine ATL model [65], and yielded a high remission rate in newly diagnosed chronic ATL patients [66]. In PEL, ATO/IFN $\alpha$ inhibited growth, induced apoptosis, and downregulated the latent viral transcripts in PEL cells derived from malignant ascites [53]. In a murine PEL model, this combination decreased the volume of peritoneal ascites, a feature imposing difficulty in treatment of several malignant lymphomatous effusions, and synergistically increased survival of PEL mice [53]. The ATO/Lena combination has been previously investigated in multiple myeloma. ATO and Lena exhibited independent non-interfering effects [67] where ATO sensitized myeloma cells to Lena via the upregulation of cereblon expression, a major target for Lena, resulting in apoptosis [68]. In a different study, the use of a supra-pharmacological dose of Lena $(50 \mathrm{mg} / \mathrm{kg} /$ day) in PEL mice induced apoptosis of PEL cell lines and decreased ascites formation in vivo [46]. In contrast, our data showed that treatment of ex vivo treated BC-3 or BCBL-1 ascites-derived PEL cells with Lena alone moderately inhibited proliferation and did not decrease peritoneal volume in vivo (Figures $1 b$ and $2 a$ ), presumably due to the 10-fold lower concentration used in our experiments. Yet, Lena alone increased survival of BC-3 injected mice and led to a cure in 25\% of BCBL-1 injected mice (Figure 1a). While ATO yielded better survival outcome in BC-3 injected mice than did Lena alone, Lena as a single agent showed a better effect on survival on BCBL-1 injected mice (Figure 1a). Yet, neither Lena nor ATO single agents exhibited any effect on peritoneal ascites volume (Figure 1b). Interestingly, ATO/Lena impeded ascites formation, decreased organ infiltration (Figures $1 \mathrm{~b}$ and $6 \mathrm{a}$ ), enhanced survival, and induced a cure in $25 \%$ and $75 \%$ of BC-3 and BCBL-1 PEL mice, respectively (Figure 1a).

KSHV latency is crucial for development of its associated malignancies [17]. The latent state of the virus still presents a substantial hurdle through promoting PEL cell proliferation and survival [17]. KSHV persists in a latent state [21] in PEL cell lines and ascites. Interestingly, ATO/Lena decreased expression of LANA-1 and LANA-2 latent proteins in malignant ascites-derived cells and in vivo (Figure 2b, Figure $6 \mathrm{~b}$ and Figure S2). Two other latent KSHV proteins, v-Cyclin and v-FLIP, are transcribed from the same promoter [69], yet an internal ribosome entry site preceding the v-FLIP start codon and overlapping the v-Cyclin coding region allows for v-FLIP translation [70]. The decreased expression of all tested latent viral genes (LANA-1, LANA-2, v-Cyclin, and v-FLIP) was consistent in both ascites-derived PEL cells (Figure 2c). v-FLIP is essential for survival of PEL cells, and its silencing results in apoptosis [29]. Moreover, v-FLIP expression in rodent cells resulted in increased proliferation and transformation, highlighting the v-FLIP oncogenic capacity [32]. The mechanism through which ATO/Lena decreased latent protein expression requires further investigation. One potential mechanism can be through the accumulation of reactive oxygen species (ROS) in PEL cells. This may result in decreased latency, viral reactivation, and apoptosis induction [71,72]. Indeed, both ATO and Lena treatments used as single agents are known to induce oxidative stress and ROS generation [52,73,74]. In multiple myeloma, Lena inhibited hydrogen peroxide decomposition, resulting in increased oxidative stress and cytotoxicity [73]. Furthermore, ROS accumulation in target cells is documented as one of the established mechanisms contributing to ATO cytotoxicity [74].

NF- $\mathrm{KB}$ activation is involved in KSHV transformation, resistance to apoptosis, and is paramount for survival of PEL cells $[33,35,75]$. Previous studies presented NF- $\mathrm{KB}$ as a potential target for therapy $[35,57]$. NF-KB inhibition prevented or delayed PEL growth and prolonged disease-free survival in mice [35]. Downregulation of v-FLIP activity resulted in decreased NF- $\mathrm{KB}$ activation and subsequent apoptosis of PEL in vitro [29]. Consistent with these reports, we demonstrate that the ATO/Lena decreased v-FLIP expression was accompanied by the inhibition of the NF- $\mathrm{kB}$ pathway (Figure 3a). PEL cells are known to produce IL-6 and IL-10 [36,37]. Indeed, v-FLIP is known to activate the IL-6 promoter through NF-KB activation [76]. On the other hand, IL-6 and IL-10 are both downstream NF- $\mathrm{kB}$ signalers. These two cytokines are known as autocrine growth factors, which promote PEL growth and proliferation [36-38]. Clinically, IL-6 and IL-10 were shown to be 
prognostic factors that contribute to clinical response and pathogenesis of PEL [77]. In accordance with these studies, NF-KB inhibition following ATO/Lena treatment was accompanied by decreased IL- 6 and IL-10 transcripts ex vivo and in vivo (Figure $3 b$ and c). The decrease in latent viral proteins expression along with the decrease in essential autocrine factors might explain the pronounced inhibition of cell proliferation inflicted by the ATO/Lena combination.

Suppression of viral lytic gene expression is a fundamental mechanism by which latency is maintained in PEL $[17,21]$. Latent proteins inhibit the KSHV lytic state and promote oncogenesis. In that sense, LANA-1 suppresses lytic gene expression by binding to gene promoters to inhibit transcription or via epigenetic silencing of the KSHV genome [19]. v-FLIP inhibits RTA promoter activity, a major lytic transactivator, and represses viral lytic replication [76]. v-FLIP mediated inhibition of lytic reactivation occurs through activation of the NF- $\mathrm{kB}$ pathway and inhibition of AP-1 [76]. In fact, deletion of v-FLIP increased expression of lytic genes and enhanced lytic replication [76]. Recently, it was shown that NF- $\mathrm{kB}$ inhibition resulted in KSHV reactivation and cell death [72]. Moreover, KSHV reactivation was proposed as a potential therapeutic approach for eradicating PEL [78]. In line with these data, and concomitant with the decreased latent viral expression and inhibition of NF- $\mathrm{KB}$ and its subsequent decrease of IL- 6 and IL-10, ATO/Lena induced an increase in the transcription of both the early viral lytic genes (RTA and ORF K8) and the late viral lytic gene (K8.1) (Figure 3c,d) and the induction of apoptosis (Figures $3 \mathrm{~b}$ and 4 ).

High levels of VEGF are secreted by PEL cells [60] and correlate with PEL progression [60,61]. Furthermore, anti-VEGF antibodies impede ascites formation in PEL mice $[38,60]$. The peritoneum of PEL mice exhibited extensive vessel formation (Figure 5a). In animals treated with ATO/Lena, there was a remarkable decrease in abdominal vascularization in BC-3 treated PEL mice (Figure 5a). This was correlated with decreased tube formation capacity in the supernatant of ascites-derived BC-3 cells treated with ATO/Lena (Figure $5 b, c)$. In ascites-derived BCBL-1 cells, basal secreted VEGF levels were much higher compared to ascites derived BC-3 cells [61]. The inability of the antibody to inhibit tube formation can be explained by the very high levels of VEGF in those cells [61].

Our study provides coherent evidence on the efficacy of ATO/Lena against PEL in vivo and ex vivo, which strongly supports the clinical testing of this combination for a better management of PEL.

\section{Materials and Methods}

\subsection{Cells, Mice, and Treatment}

The $\mathrm{KSHV}^{+} / \mathrm{EBV}^{-} \mathrm{BC}-3$ and BCBL-1 malignant $\mathrm{B}$ cell lines derived from PEL patients $[79,80]$ were obtained from Dr A. Gessain (Pasteur Institute, Paris, France). Cells were cultured in RPMI-1640 medium containing 10\% heat inactivated fetal bovine serum (FBS) and antibiotics. Six to eight week old immuno-compromised male or female NOD/SCID mice (Charles River, Ecully, France) were inoculated with 2 million BC-3 or BCBL-1 cells [81]. Starting at day 4 post-PEL inoculation, mice were injected intraperitoneally daily with ATO (Sigma Aldrich, Sigma Aldrich, MO, USA, cat\#A1010) and/or Lena (Celgene Corporation Research Alliance, Paris, France) at the dose of 5 gg/g/day [53] until day 42. None of the individual or combination treatment regimens were toxic in normal NOD/SCID mice when given for 21 days (100\% survival for $>3$ months; no observed toxicity)). Mice survival curves were presented using the Kaplan-Meier method. Statistical analysis ( $n=4$ per condition) was performed using GraphPad prism software 7.0 (GraphPad software (C), San Diego, CA, USA); a $p$ value of 0.05 was considered significant.

For therapeutic efficacy, mice were first allowed to develop PEL for 6 weeks and then were treated with ATO and/or Lena at the dose of $5 \mu \mathrm{g} / \mathrm{g} /$ day for one week. To assess ascites development, PEL NOD/SCID (PEL mice) $(n=8)$ were visually monitored and peritoneal diameter $(\mathrm{d})$ was measured using a caliber. Peritoneal volume (indicative of effusion) was calculated according to the formula: $\mathrm{v}=4 / 3 \pi(\mathrm{d} / 2)[53,82]$. Statistical analysis was performed using GraphPad prism software 7.0 and one way Anova. A $p$ value of 0.05 was considered significant. Lungs and livers from treated or 
untreated mice were fixed, embedded in paraffin, sectioned, stained with hematoxylin and eosin (H\&E), and examined by light microscopy.

Animal protocols were approved by the Institutional Animal Care and Utilization Committee (IACUC) of the American University of Beirut (AUB) under Permit Number \#15-07-P575, and mice were housed in pathogen-free facilities.

Human specific cell surface marker (CD45 phycoerythrin antibody (BD biosciences, San Jose, CA, USA) was performed on cells collected from ascites. Labeled samples were analyzed on a Guava flow cytometer (Merk Millipore, Darmstadt, Germany). Cell sorting was performed using a BD FACSAria SORB, San Jose, CA, USA).

\subsection{Ex Vivo Cell Culture and Analysis}

BC-3 and BCBL-1 were collected from ascites of PEL mice six weeks post-inoculation of cells. Cells were then cultured at the density of $2 \times 10^{5}$ cells per mL in RPMI- 1640 medium with $10 \%$ FBS and antibiotics. Cells were treated with $1 \mu \mathrm{M}$ ATO and/or $0.5 \mu \mathrm{M}$ Lena for 24, 48, 72, or $96 \mathrm{~h}$. Cell growth was assessed using trypan blue exclusion dye assay.

\subsection{Gene Expression Studies}

Total RNA from lungs of treated or untreated PEL mice or from ex vivo treated PEL cells was extracted using Trizol (Qiagen, Hilden, Germany Cat\# 79306). cDNA synthesis was performed using a Revert Aid First cDNA synthesis Kit (Thermo Scientific, Waltham, MA, USA). Syber green qRT PCR was performed using the BIORAD CFX96 machine, and the primers for qRT-PCR are listed in Table S1. In qRT-PCR, individual reactions were prepared with $0.25 \mu \mathrm{M}$ of each primer, $150 \mathrm{ng}$ of cDNA, and SYBR Green PCR Master Mix to a final volume of $10 \mu \mathrm{L}$. PCR reactions consisted of a DNA denaturation step at $95^{\circ} \mathrm{C}$ for $3 \mathrm{~min}$, followed by 39 cycles of denaturation at $95^{\circ} \mathrm{C}$ for $15 \mathrm{~s}$, annealing at $57^{\circ} \mathrm{C}$ for $60 \mathrm{~s}$, extension at $72{ }^{\circ} \mathrm{C}$ for $30 \mathrm{~s}$. For each experiment, reactions were performed in duplicate and expression of individual genes was normalized to the housekeeping gene glyceraldehyde-3-phosphate dehydrogenase (GAPDH) (Table S1). The transcript expression level was calculated according to the Livak method [83].

\subsection{Protein Expression Studies}

Ex vivo treated PEL cells were solubilized in lysis buffer. One hundred $\mu \mathrm{g}$ of protein lysates were loaded onto a $12 \%$ SDS-polyacrylamide gel, subjected to electrophoresis, and transferred onto nitrocellulose membranes. Blots were incubated overnight with specific primary antibodies against LANA-1 (NBP1-30176, Novus), LANA-2 (NB200-167H, Novus), Caspase 3 (sc-7148, Santa Cruz), PARP (sc-7150, Santa Cruz), p-IкB $\alpha$ (Invitrogen, Foster City, CA, USA)., H3 total (ab1791, Abcam, Cambridge, UK), and GAPDH (MAB5476, Abnova, Walnut, CA, USA). Blots were then incubated with appropriate HRP-conjugated secondary antibodies (m-IgGK BP-HRP sc-516102, mouse anti-rabbit IgG-HRP sc-2357, Santa Cruz, CA, USA). Bands were visualized by chemiluminescence (Clarity max, Bio-Rad, Hercules, CA, USA Cat\# 170-5061).

\subsection{Immunofluorescence Assay}

Ex vivo untreated or treated PEL cells were fixed with ice-cold methanol $\left(-20^{\circ} \mathrm{C}\right)$ for $20 \mathrm{~min}$ and cytospun onto glass slides. Following permeabilization, immunostaining was performed overnight with primary rabbit monoclonal antibody against P65 (Cell Signaling, MA, USA) and rat monoclonal antibody against LANA-1 (Abcam). Primary antibodies were revealed by Alexa Fluor 488- or Fluor 594-labeled secondary antibodies (Abcam). Staining of nuclei was performed with Hoechst (Invitrogen), and slides were mounted using prolong antifade (Invitrogen). For the apoptosis assay, cells were fixed with methanol and stained with Hoechst. Images were acquired by confocal microscopy using a Zeiss LSM710 confocal microscope (Zeiss, Oberkochen, Germany) with a Plan Apochromat 63/1.4 numeric aperture oil-immersion objective using Zen 2009 (Carl Zeiss, Oberkochen, Germany). 


\subsection{Matrigel-Induced Capillary Tube Formation}

Twenty-four-well plates were pre-coated with $200 \mu \mathrm{L}$ of gelled growth factor-reduced Matrigel (Becton Dickinson, San Jose, CA, USA). Human aortic endothelial cells (HAEC) were seeded at the density of $8 \times 10^{4}$ cells for $18 \mathrm{~h}$. Ascites-derived BC-3 or BCBL-1 PEL cells were pelleted and cultured for $48 \mathrm{~h}$ in serum-free media. The resulting supernatants from treated or untreated cells were added for $48 \mathrm{~h}$. VEGF was used as a positive control and Bivacizumab to neutralize VEGF as a negative control [84]. Plates were photographed using a Zeiss light microscope and analyzed using Zeiss Zen software. Quantification was performed by counting the nodes, defined as joint point of 3 or more branches [85]. Data was presented as percentage of control/untreated cells.

\section{Conclusions}

Our study depicts ATO/Lena as a promising therapeutic target for PEL. Current PEL regimen relies on chemotherapy, which fails to maintain satisfactory clinical response. Thus, PEL is associated with a dismal prognosis and high relapse rate.

ATO/Lena resulted in enhanced survival and cured PEL mice in vivo. The mechanism of action of $\mathrm{ATO} /$ Lena was unveiled: ATO/Lena decreased expression of latent viral proteins, decreased NF- $\mathrm{kB}$ activation and cytokine production, and increased lytic gene expression. All of which contributed to induction of apoptosis. Our study warrants the further clinical investigation of the efficacy of ATO/Lena in PEL patients.

Supplementary Materials: The following are available online at http:/www.mdpi.com/2072-6694/12/9/2483/s1, Figure S1: ATO/Lena decreased peritoneal volume in PEL mice. Figure S2: ATO/Lena decreased LANA-1 expression in ascites-derived BC-3 and BCBL-1 PEL cells. Figure S3: ATO/Lena induced apoptosis in ascites-derived BC-3 and BCBL-1 PEL cells, Figure S4: CD45 staining of peritoneal ascites from PEL mice, Figure S5: Uncropped Western blot figures. Table S1: List of primers used for RT-qPCR.

Author Contributions: Study concept and design, H.E.H.; Experimental work, S.M., R.E.H., L.H., R.H., M.H., M.K., N.T., R.A.M.; Drafting of the manuscript, S.M.; Critical revision of manuscript for intellectual content, H.E.H., M.E.S.; Statistical analysis, S.M., R.E.H. All authors have read and agreed to the published version of the manuscript.

Funding: The American University of Beirut and the National Council for Scientific Research of Lebanon (CNRS-L) for granting a doctoral fellowship to Ms. Sara Moodad.

Acknowledgments: The authors thank Celgene for providing Lenalidomide, the American University of Beirut core facilities, and Ali Bazarbachi for the thorough reading of the manuscript. The authors would like to acknowledge the American University of Beirut (AUB) and the National Council for Scientific Research of Lebanon (CNRS-L) for granting a doctoral fellowship in Biomedical sciences to Sara Moodad.

Conflicts of Interest: The authors declare no conflict of interest.

\section{References}

1. Katano, H. Pathological Features of Kaposi's Sarcoma-Associated Herpesvirus Infection. In Human Herpesviruses; Kawaguchi, Y., Mori, Y., Kimura, H., Eds.; Springer: Singapore, 2018; pp. 357-376.

2. Shimada, K.; Hayakawa, F.; Kiyoi, H. Biology and management of primary effusion lymphoma. Blood 2018, 132, 1879-1888. [CrossRef] [PubMed]

3. Chang, Y.; Cesarman, E.; Pessin, M.; Lee, F.; Culpepper, J.; Knowles, D.; Moore, P. Identification of herpesvirus-like DNA sequences in AIDS-associated Kaposi's sarcoma. Science 1994, 266, 1865-1869. [CrossRef] [PubMed]

4. Cesarman, E.; Chang, Y.; Moore, P.S.; Said, J.W.; Knowles, D.M. Kaposi's Sarcoma-Associated Herpesvirus-Like DNA Sequences in AIDS-Related Body-Cavity-Based Lymphomas. N. Engl. J. Med. 1995, 332, 1186-1191. [CrossRef] [PubMed]

5. Minhas, V.; Wood, C. Epidemiology and Transmission of Kaposi's Sarcoma-Associated Herpesvirus. Viruses 2014, 6, 4178-4194. [CrossRef]

6. Chen, Y.B.; Rahemtullah, A.; Hochberg, E. Primary effusion lymphoma. Oncologist 2007, 12, 569-576. [CrossRef] 
7. Boulanger, E.; Hermine, O.; Fermand, J.-P.; Radford-Weiss, I.; Brousse, N.; Meignin, V.; Gessain, A. Human herpesvirus 8 (HHV-8)-associated peritoneal primary effusion lymphoma (PEL) in two HIV-negative elderly patients. Am. J. Hematol. 2004, 76, 88-91. [CrossRef]

8. Boulanger, E.; Afonso, P.V.; Yahiaoui, Y.; Adle-Biassette, H.; Gabarre, J.; Agbalika, F. Human Herpesvirus-8 (HHV-8)-Associated Primary Effusion Lymphoma in two Renal Transplant Recipients Receiving Rapamycin. Am. J. Transplant. 2008, 8, 707-710. [CrossRef]

9. Sasaki, Y.; Isegawa, T.; Shimabukuro, A.; Yonaha, T.; Yonaha, H. Primary Effusion Lymphoma in an Elderly HIV-Negative Patient with Hemodialysis: Importance of Evaluation for Pleural Effusion in Patients Receiving Hemodialysis. Case Rep. Nephrol. Dial. 2014, 4, 95-102. [CrossRef]

10. Said, J.W.; Tasaka, T.; Takeuchi, S.; Asou, H.; de Vos, S.; Cesarman, E.; Knowles, D.M.; Koeffler, H. Primary effusion lymphoma in women: Report of two cases of Kaposi's sarcoma herpes virus-associated effusion-based lymphoma in human immunodeficiency virus-negative women. Blood 1996, 88, 3124-3128. [CrossRef]

11. Arora, N.; Gupta, A.; Sadeghi, N. Primary effusion lymphoma: Current concepts and management. Curr. Opin. Pulm. Med. 2017, 23, 365-370. [CrossRef] [PubMed]

12. Medeiros, B.C.; Maness, L.J.; Bauer, F.A.; Ross, J.W.; Kapur, D. Unusual presentation of "extracavitary" primary effusion lymphoma in previously unknown HIV disease. Conn. Med. 2000, 64, 591-594. [PubMed]

13. Chadburn, A.; Hyjek, E.; Mathew, S.; Cesarman, E.; Said, J.; Knowles, D.M. KSHV-Positive Solid Lymphomas Represent an Extra-Cavitary Variant of Primary Effusion Lymphoma. Am. J. Surg. Pathol. 2004, 28, 1401-1416. [CrossRef] [PubMed]

14. Kaplan, L.D. Human herpesvirus-8: Kaposi sarcoma, multicentric Castleman disease, and primary effusion lymphoma. Hematol. Am. Soc. Hematol. Educ. Program. 2013, 2013, 103-108. [CrossRef]

15. Carbone, A.; Gloghini, A. KSHV/HHV8-associated lymphomas. Br. J. Haematol. 2008, 140, 13-24. [CrossRef] [PubMed]

16. Said, J. Kaposi's sarcoma-associated herpesvirus (KSHV): A new viral pathogen associated with Kaposi's sarcoma, primary effusion lymphoma, and multicentric Castleman's disease. West J. Med. 1997, 167, 37-38.

17. Wen, K.W.; Damania, B. Kaposi sarcoma-associated herpesvirus (KSHV): Molecular biology and oncogenesis. Cancer Lett. 2010, 289, 140-150. [CrossRef] [PubMed]

18. Kedes, D.H.; Lagunoff, M.; Renne, R.; Ganem, D. Identification of the gene encoding the major latency-associated nuclear antigen of the Kaposi's sarcoma-associated herpesvirus. J. Clin. Investig. 1997, 100, 2606-2610. [CrossRef] [PubMed]

19. Uppal, T.; Banerjee, S.; Sun, Z.; Verma, S.C.; Robertson, E.S. KSHV LANA-the master regulator of KSHV latency. Viruses 2014, 6, 4961-4998. [CrossRef]

20. Schulz, T.F.; Cesarman, E. Kaposi Sarcoma-associated Herpesvirus: Mechanisms of oncogenesis. Curr. Opin. Virol. 2015, 14, 116-128. [CrossRef]

21. Yan, L.; Majerciak, V.; Zheng, Z.M.; Lan, K. Towards Better Understanding of KSHV Life Cycle: From Transcription and Posttranscriptional Regulations to Pathogenesis. Virol. Sin. 2019, 34, 135-161. [CrossRef]

22. Patel, R.M.; Goldblum, J.R.; Hsi, E.D. Immunohistochemical detection of human herpes virus-8 latent nuclear antigen-1 is useful in the diagnosis of Kaposi sarcoma. Mod. Pathol. 2004, 17, 456-460. [CrossRef] [PubMed]

23. Fukumoto, H.; Kanno, T.; Hasegawa, H.; Katano, H. Pathology of Kaposi's Sarcoma-Associated Herpesvirus Infection. Front. Microbiol. 2011, 2, 175. [CrossRef] [PubMed]

24. Cai, Q.L.; Knight, J.S.; Verma, S.C.; Zald, P.; Robertson, E.S. EC5S ubiquitin complex is recruited by KSHV latent antigen LANA for degradation of the VHL and p53 tumor suppressors. PLoS Pathog. 2006, 2, e116. [CrossRef] [PubMed]

25. DeCotiis, J.L.; Lukac, D.M. KSHV and the Role of Notch Receptor Dysregulation in Disease Progression. Pathogens 2017, 6, 34. [CrossRef]

26. Wies, E.; Mori, Y.; Hahn, A.; Kremmer, E.; Stürzl, M.; Fleckenstein, B.; Neipel, F. The viral interferon-regulatory factor-3 is required for the survival of KSHV-infected primary effusion lymphoma cells. Blood 2008, 111, 320-327. [CrossRef]

27. Muñoz-Fontela, C.; Marcos-Villar, L.; Hernandez, F.; Gallego, P.; Rodriguez, E.; Arroyo, J.; Gao, S.J.; Avila, J.; Rivas, C. Induction of paclitaxel resistance by the Kaposi's sarcoma-associated herpesvirus latent protein LANA2. J. Virol. 2008, 82, 1518-1525. [CrossRef] 
28. Godden-Kent, D.; Talbot, S.J.; Boshoff, C.; Chang, Y.; Moore, P.; Weiss, R.A.; Mittnacht, S. The cyclin encoded by Kaposi's sarcoma-associated herpesvirus stimulates cdk6 to phosphorylate the retinoblastoma protein and histone H1. J. Virol. 1997, 71, 4193-4198. [CrossRef]

29. Guasparri, I.; Keller, S.A.; Cesarman, E. KSHV vFLIP is essential for the survival of infected lymphoma cells. J. Exp. Med. 2004, 199, 993-1003. [CrossRef]

30. Bélanger, C.; Gravel, A.; Tomoiu, A.; Janelle, M.E.; Gosselin, J.; Tremblay, M.J.; Flamand, L. Human herpesvirus 8 viral FLICE-inhibitory protein inhibits Fas-mediated apoptosis through binding and prevention of procaspase-8 maturation. J. Hum. Virol. 2001, 4, 62-73.

31. Thome, M.; Schneider, P.; Hofmann, K.; Fickenscher, H.; Meinl, E.; Neipel, F.; Mattmann, C.; Burns, K.; Bodmer, J.L.; Schröter, M.; et al. Viral FLICE-inhibitory proteins (FLIPs) prevent apoptosis induced by death receptors. Nature 1997, 386, 517-521. [CrossRef]

32. Sun, Q.; Zachariah, S.; Chaudhary, P.M. The human herpes virus 8-encoded viral FLICE-inhibitory protein induces cellular transformation via NF-kappaB activation. J. Biol. Chem. 2003, 278, 52437-52445. [CrossRef] [PubMed]

33. Field, N.; Low, W.; Daniels, M.; Howell, S.; Daviet, L.; Boshoff, C.; Collins, M. KSHV vFLIP binds to IKK-gamma to activate IKK. J. Cell Sci. 2003, 116 Pt 18, 3721-3728. [CrossRef]

34. Chaudhary, P.M.; Jasmin, A.; Eby, M.T.; Hood, L. Modulation of the NF-kappa B pathway by virally encoded death effector domains-containing proteins. Oncogene 1999, 18, 5738-5746. [CrossRef] [PubMed]

35. Keller, S.A.; Hernandez-Hopkins, D.; Vider, J.; Ponomarev, V.; Hyjek, E.; Schattner, E.J.; Cesarman, E. NF-kappaB is essential for the progression of KSHV- and EBV-infected lymphomas in vivo. Blood 2006, 107, 3295-3302. [CrossRef] [PubMed]

36. Foussat, A.; Wijdenes, J.; Bouchet, L.; Gaidano, G.; Neipel, F.; Balabanian, K.; Galanaud, P.; Couderc, J.; Emilie, D. Human interleukin-6 is in vivo an autocrine growth factor for human herpesvirus-8-infected malignant B lymphocytes. Eur. Cytokine Netw. 1999, 10, 501-508. [PubMed]

37. Jones, K.D.; Aoki, Y.; Chang, Y.; Moore, P.S.; Yarchoan, R.; Tosato, G. Involvement of interleukin-10 (IL-10) and viral IL-6 in the spontaneous growth of Kaposi's sarcoma herpesvirus-associated infected primary effusion lymphoma cells. Blood 1999, 94, 2871-2879. [CrossRef]

38. Goto, H.; Kudo, E.; Kariya, R.; Taura, M.; Katano, H.; Okada, S. Targeting VEGF and interleukin-6 for controlling malignant effusion of primary effusion lymphoma. J. Cancer Res. Clin. Oncol. 2015, 141, 465-474. [CrossRef]

39. Okada, S.; Goto, H.; Yotsumoto, M. Current status of treatment for primary effusion lymphoma. Intractable Rare Dis. Res. 2014, 3, 65-74. [CrossRef]

40. Narkhede, M.; Arora, S.; Ujjani, C. Primary effusion lymphoma: Current perspectives. Onco Targets Ther. 2018, 11, 3747-3754. [CrossRef]

41. Li, S.; Bai, L.; Dong, J.; Sun, R.; Lan, K. Kaposi's Sarcoma-Associated Herpesvirus: Epidemiology and Molecular Biology. Adv. Exp. Med. Biol. 2017, 1018, 91-127. [CrossRef]

42. Dimopoulos, M.; Spencer, A.; Attal, M.; Prince, H.M.; Harousseau, J.L.; Dmoszynska, A.; San Miguel, J.; Hellmann, A.; Facon, T.; Foà, R.; et al. Lenalidomide plus dexamethasone for relapsed or refractory multiple myeloma. N. Engl. J. Med. 2007, 357, 2123-2132. [CrossRef]

43. Shortt, J.; Hsu, A.K.; Johnstone, R.W. Thalidomide-analogue biology: Immunological, molecular and epigenetic targets in cancer therapy. Oncogene 2013, 32, 4191-4202. [CrossRef] [PubMed]

44. Flowers, C.R.; Leonard, J.P.; Fowler, N.H. Lenalidomide in follicular lymphoma. Blood 2020, 135, $2133-2136$. [CrossRef] [PubMed]

45. Hernandez-Ilizaliturri, F.J.; Batoo, S.A. The emerging role of lenalidomide in the management of lymphoid malignancies. Ther. Adv. Hematol. 2011, 2, 45-53. [CrossRef] [PubMed]

46. Gopalakrishnan, R.; Matta, H.; Tolani, B.; Triche, T., Jr.; Chaudhary, P.M. Immunomodulatory drugs target IKZF1-IRF4-MYC axis in primary effusion lymphoma in a cereblon-dependent manner and display synergistic cytotoxicity with BRD4 inhibitors. Oncogene 2016, 35, 1797-1810. [CrossRef] [PubMed]

47. Davis, D.A.; Mishra, S.; Anagho, H.A.; Aisabor, A.I.; Shrestha, P.; Wang, V.; Takamatsu, Y.; Maeda, K.; Mitsuya, H.; Zeldis, J.B.; et al. Restoration of immune surface molecules in Kaposi sarcoma-associated herpes virus infected cells by lenalidomide and pomalidomide. Oncotarget 2017, 8, 50342-50358. [CrossRef] 
48. Antar, A.; El Hajj, H.; Jabbour, M.; Khalifeh, I.; El-Merhi, F.; Mahfouz, R.; Bazarbachi, A. Primary effusion lymphoma in an elderly patient effectively treated by lenalidomide: Case report and review of literature. Blood Cancer J. 2014, 4, e190. [CrossRef]

49. Ghavamzadeh, A.; Alimoghaddam, K.; Rostami, S.; Ghaffari, S.H.; Jahani, M.; Iravani, M.; Mousavi, S.A.; Bahar, B.; Jalili, M. Phase II study of single-agent arsenic trioxide for the front-line therapy of acute promyelocytic leukemia. J. Clin. Oncol. 2011, 29, 2753-2757. [CrossRef]

50. Powell, B.L.; Moser, B.; Stock, W.; Gallagher, R.E.; Willman, C.L.; Stone, R.M.; Rowe, J.M.; Coutre, S.; Feusner, J.H.; Gregory, J.; et al. Arsenic trioxide improves event-free and overall survival for adults with acute promyelocytic leukemia: North American Leukemia Intergroup Study C9710. Blood 2010, 116, 3751-3757. [CrossRef]

51. Kchour, G.; Rezaee, R.; Farid, R.; Ghantous, A.; Rafatpanah, H.; Tarhini, M.; Kooshyar, M.M.; El Hajj, H.; Berry, F.; Mortada, M.; et al. The combination of arsenic, interferon-alpha, and zidovudine restores an "immunocompetent-like" cytokine expression profile in patients with adult T-cell leukemia lymphoma. Retrovirology 2013, 10, 91. [CrossRef]

52. Miller, W.H., Jr.; Schipper, H.M.; Lee, J.S.; Singer, J.; Waxman, S. Mechanisms of action of arsenic trioxide. Cancer Res. 2002, 62, 3893-3903. [PubMed]

53. Abou-Merhi, R.; Khoriaty, R.; Arnoult, D.; El Hajj, H.; Dbouk, H.; Munier, S.; El-Sabban, M.E.; Hermine, O.; Gessain, A.; de Thé, H.; et al. PS-341 or a combination of arsenic trioxide and interferon-alpha inhibit growth and induce caspase-dependent apoptosis in KSHV/HHV-8-infected primary effusion lymphoma cells. Leukemia 2007, 21, 1792-1801. [CrossRef] [PubMed]

54. El Hajj, H.; Ali, J.; Ghantous, A.; Hodroj, D.; Daher, A.; Zibara, K.; Journo, C.; Otrock, Z.; Zaatari, G.; Mahieux, R.; et al. Combination of arsenic and interferon-alpha inhibits expression of KSHV latent transcripts and synergistically improves survival of mice with primary effusion lymphomas. PLoS ONE 2013, 8, e79474. [CrossRef] [PubMed]

55. Brown, H.J.; Song, M.J.; Deng, H.; Wu, T.T.; Cheng, G.; Sun, R. NF-kappaB inhibits gammaherpesvirus lytic replication. J. Virol. 2003, 77, 8532-8540. [CrossRef] [PubMed]

56. Grossmann, C.; Ganem, D. Effects of NFkappaB activation on KSHV latency and lytic reactivation are complex and context-dependent. Virology 2008, 375, 94-102. [CrossRef] [PubMed]

57. Keller, S.A.; Schattner, E.J.; Cesarman, E. Inhibition of NF-kappaB induces apoptosis of KSHV-infected primary effusion lymphoma cells. Blood 2000, 96, 2537-2542. [CrossRef]

58. Buesche, G.; Dieck, S.; Giagounidis, A.; Bock, O.; Wilkens, L.; Schlegelberger, B.; Knight, R.; Bennett, J.; Aul, C.; Kreipe, H.H. Anti-Angiogenic In Vivo Effect of Lenalidomide (CC-5013) in Myelodysplastic Syndrome with $\operatorname{del}(5 q)$ Chromosome Abnormality and Its Relation to the Course of Disease. Blood 2005, 106, 372. [CrossRef]

59. Kotla, V.; Goel, S.; Nischal, S.; Heuck, C.; Vivek, K.; Das, B.; Verma, A. Mechanism of action of lenalidomide in hematological malignancies. J. Hematol. Oncol. 2009, 2, 36. [CrossRef]

60. Aoki, Y.; Tosato, G. Vascular endothelial growth factor/vascular permeability factor in the pathogenesis of primary effusion lymphomas. Leuk. Lymphoma 2001, 41, 229-237. [CrossRef]

61. Haddad, L.; El Hajj, H.; Abou-Merhi, R.; Kfoury, Y.; Mahieux, R.; El-Sabban, M.; Bazarbachi, A. KSHV-transformed primary effusion lymphoma cells induce a VEGF-dependent angiogenesis and establish functional gap junctions with endothelial cells. Leukemia 2008, 22, 826-834. [CrossRef]

62. El Hajj, H.; Dassouki, Z.; Berthier, C.; Raffoux, E.; Ades, L.; Legrand, O.; Hleihel, R.; Sahin, U.; Tawil, N.; Salameh, A.; et al. Retinoic acid and arsenic trioxide trigger degradation of mutated NPM1, resulting in apoptosis of AML cells. Blood 2015, 125, 3447-3454. [CrossRef] [PubMed]

63. Martelli, M.P.; Gionfriddo, I.; Mezzasoma, F.; Milano, F.; Pierangeli, S.; Mulas, F.; Pacini, R.; Tabarrini, A.; Pettirossi, V.; Rossi, R.; et al. Arsenic trioxide and all-trans retinoic acid target NPM1 mutant oncoprotein levels and induce apoptosis in NPM1-mutated AML cells. Blood 2015, 125, 3455-3465. [CrossRef] [PubMed]

64. Bazarbachi, A.; El-Sabban, M.E.; Nasr, R.; Quignon, F.; Awaraji, C.; Kersual, J.; Dianoux, L.; Zermati, Y.; Haidar, J.H.; Hermine, O.; et al. Arsenic trioxide and interferon-alpha synergize to induce cell cycle arrest and apoptosis in human T-cell lymphotropic virus type I-transformed cells. Blood 1999, 93, 278-283. [CrossRef] [PubMed]

65. El Hajj, H.; El-Sabban, M.; Hasegawa, H.; Zaatari, G.; Ablain, J.; Saab, S.T.; Janin, A.; Mahfouz, R.; Nasr, R.; Kfoury, Y.; et al. Therapy-induced selective loss of leukemia-initiating activity in murine adult $\mathrm{T}$ cell leukemia. J. Exp. Med. 2010, 207, 2785-2792. [CrossRef] 
66. Kchour, G.; Tarhini, M.; Kooshyar, M.M.; El Hajj, H.; Wattel, E.; Mahmoudi, M.; Hatoum, H.; Rahimi, H.; Maleki, M.; Rafatpanah, H.; et al. Phase 2 study of the efficacy and safety of the combination of arsenic trioxide, interferon alpha, and zidovudine in newly diagnosed chronic adult T-cell leukemia/lymphoma (ATL). Blood 2009, 113, 6528-6532. [CrossRef]

67. Wang, H.; Chen, X.; Eksioglu, E.; Zhou, J.; Fortenbery, N.; Djeu, J.; List, A.; Wei, S. Lenalidomide and Arsenic Trioxide Have Independent Non-Interfering Effects When Used in Combination on Myeloma Cell Lines in Vitro. J. Cancer Ther. 2013, 4, 787-796. [CrossRef]

68. Jian, Y.; Gao, W.; Geng, C.; Zhou, H.; Leng, Y.; Li, Y.; Chen, W. Arsenic trioxide potentiates sensitivity of multiple myeloma cells to lenalidomide by upregulating cereblon expression levels. Oncol. Lett. 2017, 14, 3243-3248. [CrossRef]

69. Pearce, M.; Matsumura, S.; Wilson, A.C. Transcripts encoding K12, v-FLIP, v-cyclin, and the microRNA cluster of Kaposi's sarcoma-associated herpesvirus originate from a common promoter. J. Virol. 2005, 79, 14457-14464. [CrossRef]

70. Low, W.; Harries, M.; Ye, H.; Du, M.Q.; Boshoff, C.; Collins, M. Internal ribosome entry site regulates translation of Kaposi's sarcoma-associated herpesvirus FLICE inhibitory protein. J. Virol. 2001, 75, 2938-2945. [CrossRef]

71. Ye, F.; Zhou, F.; Bedolla, R.G.; Jones, T.; Lei, X.; Kang, T.; Guadalupe, M.; Gao, S.J. Reactive oxygen species hydrogen peroxide mediates Kaposi's sarcoma-associated herpesvirus reactivation from latency. PLoS Pathog. 2011, 7, e1002054. [CrossRef]

72. Li, X.; Feng, J.; Sun, R. Oxidative Stress Induces Reactivation of Kaposi's Sarcoma-Associated Herpesvirus and Death of Primary Effusion Lymphoma Cells. J. Virol. 2011, 85, 715-724. [CrossRef] [PubMed]

73. Sebastian, S.; Zhu, Y.X.; Braggio, E.; Shi, C.-X.; Panchabhai, S.C.; Van Wier, S.A.; Ahmann, G.J.; Chesi, M.; Bergsagel, P.L.; Stewart, A.K.; et al. Multiple myeloma cells' capacity to decompose $\mathrm{H}_{2} \mathrm{O}_{2}$ determines lenalidomide sensitivity. Blood 2017, 129, 991-1007. [CrossRef] [PubMed]

74. Hu, Y.; Li, J.; Lou, B.; Wu, R.; Wang, G.; Lu, C.; Wang, H.; Pi, J.; Xu, Y. The Role of Reactive Oxygen Species in Arsenic Toxicity. Biomolecules 2020, 10, 240. [CrossRef] [PubMed]

75. Hussain, A.R.; Ahmed, S.O.; Ahmed, M.; Khan, O.S.; Al Abdulmohsen, S.; Platanias, L.C.; Al-Kuraya, K.S.; Uddin, S. Cross-talk between NFkB and the PI3-kinase/AKT pathway can be targeted in primary effusion lymphoma (PEL) cell lines for efficient apoptosis. PLoS ONE 2012, 7, e39945. [CrossRef]

76. An, J.; Sun, Y.; Sun, R.; Rettig, M.B. Kaposi's sarcoma-associated herpesvirus encoded vFLIP induces cellular IL-6 expression: The role of the NF-kappaB and JNK/AP1 pathways. Oncogene 2003, 22, 3371-3385. [CrossRef]

77. Lurain, K.; Polizzotto, M.N.; Aleman, K.; Bhutani, M.; Wyvill, K.M.; Gonçalves, P.H.; Ramaswami, R.; Marshall, V.A.; Miley, W.; Steinberg, S.M.; et al. Viral, immunologic, and clinical features of primary effusion lymphoma. Blood 2019, 133, 1753-1761. [CrossRef]

78. Zhou, F.; Shimoda, M.; Olney, L.; Lyu, Y.; Tran, K.; Jiang, G.; Nakano, K.; Davis, R.R.; Tepper, C.G.; Maverakis, E.; et al. Oncolytic Reactivation of KSHV as a Therapeutic Approach for Primary Effusion Lymphoma. Mol. Cancer Ther. 2017, 16, 2627-2638. [CrossRef]

79. Renne, R.; Zhong, W.; Herndier, B.; McGrath, M.; Abbey, N.; Kedes, D.; Ganem, D. Lytic growth of Kaposi's sarcoma-associated herpesvirus (human herpesvirus 8) in culture. Nat. Med. 1996, 2, 342-346. [CrossRef]

80. Arvanitakis, L.; Mesri, E.A.; Nador, R.G.; Said, J.W.; Asch, A.S.; Knowles, D.M.; Cesarman, E. Establishment and characterization of a primary effusion (body cavity-based) lymphoma cell line (BC-3) harboring kaposi's sarcoma-associated herpesvirus (KSHV/HHV-8) in the absence of Epstein-Barr virus. Blood 1996, 88, 2648-2654. [CrossRef]

81. Wu, W.; Rochford, R.; Toomey, L.; Harrington, W., Jr.; Feuer, G. Inhibition of HHV-8/KSHV infected primary effusion lymphomas in NOD/SCID mice by azidothymidine and interferon-alpha. Leuk. Res. 2005, 29, 545-555. [CrossRef]

82. Tomayko, M.M.; Reynolds, C.P. Determination of subcutaneous tumor size in athymic (nude) mice. Cancer Chemother. Pharm. 1989, 24, 148-154. [CrossRef] [PubMed]

83. Schmittgen, T.D.; Livak, K.J. Analyzing real-time PCR data by the comparative C(T) method. Nat. Protoc. 2008, 3, 1101-1108. [CrossRef] 
84. Albini, A. Tumor and endothelial cell invasion of basement membranes. The matrigel chemoinvasion assay as a tool for dissecting molecular mechanisms. Pathol. Oncol. Res. 1998, 4, 230-241. [CrossRef] [PubMed]

85. Ghayad, S.E.; Rammal, G.; Ghamloush, F.; Basma, H.; Nasr, R.; Diab-Assaf, M.; Chelala, C.; Saab, R. Exosomes derived from embryonal and alveolar rhabdomyosarcoma carry differential miRNA cargo and promote invasion of recipient fibroblasts. Sci. Rep. 2016, 6, 37088. [CrossRef] [PubMed]

(C) 2020 by the authors. Licensee MDPI, Basel, Switzerland. This article is an open access article distributed under the terms and conditions of the Creative Commons Attribution (CC BY) license (http://creativecommons.org/licenses/by/4.0/). 